\title{
MAKNA TRANSPARANSI DALAM PENGELOLAAN KEUANGAN DAERAH
}

\author{
Agustinus Salle ${ }^{1}$
}

\begin{abstract}
This article explained transparency sets as a public policy to overcome asymmetric information in regional public finance that could lead to low public trust to local governments.. This referred to issues in local governments' transparency such as defining the transparency, pressures for transparency, resistant behaviours, impacts of low transparency and alternative policies to improve financial transparency in Papua.
\end{abstract}

Key words: transparency, regional finance, special autonomy.

\section{PENDAHULUAN}

Pelayanan masyarakat yang makin meningkat dan berkualitas selalu menjadi perhatian publik. Sejalan dengan peningkatan pelayanan yang lebih baik ini publik juga membutuhkan transparansi keuangan. Transparansi keuangan diartikan sebagai penyampaian informasi keuangan kepada masyarakat luas (warga), dalam rangka pertanggungjawaban pemerintah, kepatuhan pemerintah terhadap ketentuan dan peraturan yang berlaku, dan meningkatkan efektifitas pengawasan masyarakat terhadap pembangunan dan pelayanan.

Transparansi keuangan telah menjadi kebutuhan warga dan telah mendapat perhatian Pemerintah Indonesia. Sejak ditetapkannya UndangUndang Nomor 17 Tahun 2003 tentang Keuangan Negara (UU17/2003), Indonesia secara formal telah berkomitmen untuk mengelola keuangan yang mengadopsi pilar-pilar utama tata pemerintahan yang baik (good governance), yaitu transparansi, akuntabilitas, partisipasi dan kepatuhan.

\footnotetext{
${ }^{1}$ Ketua Program Studi Magister Keuangan Daerah Program Pascasarjana Universitas Cenderawasih, dan Staf Dosen Jurusan Akuntansi Fakultas Ekonomi Dan Bisnis Universitas Cenderawasih.
} 
Pilar-pilar ini menjadi azas dalam semua peraturan pelaksanaan UU17/2003.

Komitmen pemerintah untuk mendukung pelaksanaan transparansi bahkan telah direalisir melalui penetapan Undang-Undang Nomor 14 tahun 2008 tentang Keterbukaan Informasi Publik (UU14/2008). Sejumlah perangkat aturan pelaksanaan di tigkat kementrian dan pemerintah daerah telah mengatur bagaimana implementasi UU14/2008 ini.

Walau komitmen dan ketentuan perundangan sudah ditetapkan untuk mengatur transparansi keuangan, masih banyak masalah dalam implementasi di lapangan. Paper ini menjelaskan fenomena transparansi keuangan di era otonomi khusus Papua.

\section{APA PERLUNYA TRANSPARANSI KEUANGAN?}

Dapat dipastikan banyak orang yang bertanya mengapa keuangan yang dikelola suatu lembaga publik harus transparan atau terbuka untuk diketahui warganya? Ada beberapa penjelasan yang dapat menerangkan mengapa transparansi keuangan lembaga publik sangat penting:

Pertama, untuk meningkatkan kepercayaan (trust). Pemerintah yang terbuka menyampaikan informasi keuangan kepada publik lebih dipercaya dibanding pemerintah yang relatif tertutup. Medina and Rufín (2015) menjelakan bahwa "transparency does have both a direct effect on trust and an indirect effect that is mediated by satisfaction." Pemerintah yang tertutup dengan informasi keuangan dapat dinilai warga memiliki setumpuk rahasia penyelewengan keuangan. Pemerintah menutup informasi keuangan dapat diduga kurang berkompeten dalam mengelola dan melaporkan keuangan. Umumnya. pemerintah yang tertutup tidak dapat menjelaskan mengapa kinerja pembangunan mereka buruk dan tidak berhasil. 
Kedua, untuk meningkatkan pengawasan masyarakat (controlling). Untuk mengefektifkan pelaksanaan pembangunan warga perlu disertkan dalam pengawasan, dan pengawasan masyarkat ini akan efektif bila warga masyarakat mendapat informasi tentang pembiayaan program/kegiatan. Warga menjadi "watch dog" di tingkat lapangan bila perangkat pemerintah tidak ada disana. Pemerintah mempunyai keterbatasan dalam melakukan mengawasan program dan kegiatan, dan untuk itu membutuhkan dukungan warga masyarakat. Warga masyarkat dapat menilai dan memberikan masukan untuk berbagai kekurangan atau kelalaian pelaksanaan program/kegiatan di bila pemerintah transparan dalam penyampaian informasi keuangan program/kegiatan.

Ketiga, bahwa warga berhak untuk mendapatkan informasi dan hak untuk mengetahui (right to inform and right to know). Pasal 14 Undang-Undang Nomor 39 Tahun 1999 Tentang Hak Asasi Manusia menyatakan "setiap orang berhak untuk berkomunikasi dan memperoleh informasi yang diperlukan untuk mengembangkan pribadi dan lingkungan sosialnya". Hak-hak warga negara menjadi perhatian dan ukuran kualitas demokrasi di setiap negara. Warga mempunyai hak untuk mendapatkan informasi dan mengetahui kebijakan, program, dan kegiatan pemerintah yang secara langsung atau tidak langsung berdampak pada kehidupan warga dan masyarakat. Keuangan yang dialokasi pemerintah juga harus diinformasikan secara terbuka (transparan) agar warga dapat menilai kecukupan atau kekurangan untuk membiayai kebijakan, program, dan kegiatan.

\section{TRANSPARANSI DALAM REGULASI}

Transparansi keuangan pertama kali disebut dalam UndangUndang 17 tahun 2003 tentang Keuangan Negara (UU17/2003). Dalam penjelasan UU 17/2003 disebutkan bahwa

Salah satu upaya konkrit untuk mewujudkan transparansi dan akuntabilitas pengelolaan keuangan negara adalah penyampaian 
laporan pertanggungjawaban keuangan pemerintah yang memenuhi prinsip-prinsip tepat waktu dan disusun dengan mengikuti standar akuntansi pemerintah yang telah diterima secara umum.

Kebutuhan transparansi keuangan pertama kali disebut dalam Undang-Undang 17 tahun 2003 tentang Keuangan Negara (UU17/2003). Dalam UU 17/2003 tersebut transparansi ditetapkan sebagai salah satu asas bahwa pertanggungjawaban keuangan negara merupakan keniscayaan. Pemerintah wajib transparan dalam pengelolaan dan pertanggungjawaban keuangan negara. Penyampain laporan keuangan kepada publik merupakan wujud "transparansi" dan "akuntabilitas" pengelolaan keuangan negara. Selanjutnya ditetapkan bahwa dalam rangka transparansi dan akuntabilitas disusun Standar Akuntansi Pemerintahan (SAP) (UU 1/2004 tentang Perbendaharaan Negara).

Definisi transparansi didapatkan dalam Peraturan Pemerintah yang mengatur Standar Akuntansi Pemerintahan yaitu Peraturan Pemerintah Nomor 24 Tahunm 2004 (PP24/2004) yang telah diganti melalui PP71/2010. Dalam kedua peraturan ini ditemukan batasan "transparansi":

Memberikan informasi keuangan yang terbuka dan jujur kepada masyarakat berdasarkan pertimbangan bahwa masyarakat memiliki hak untuk mengetahui secara terbuka dan menyeluruh atas pertanggungjawaban pemerintah dalam pengelolaan sumber daya yang dipercayakan kepadanya dan ketaatannya pada peraturan perundang undangan.

Definisi ini menegaskan bahwa transparansi keuangan merupakan wujud keterbukaan informasi keuangan kepada publik. Makna yang terkandung bahwa pemerintah sebagai badan publik harus menyediakan informasi kepada publik. Pertanyaan berikut muncul tentang alasan "mengapa pemerintah harus transparan kepada warga/masayarakat?"

Regulasi menjelaskan beberapa alasan yang mengharuskan badan publik transparan dalam hal informasi kepada warga masyarakat. 
Alasan-alasan ini diatur dalam Pasal 3 UU 14 tahun 2008 tentang Keterbukaan Informasi Publik (KIP).

a. menjamin hak warga negara untuk mengetahui rencana pembuatan kebijakan publik, program kebijakan publik, dan proses pengambilan keputusan publik, serta alasan pengambilan suatu keputusan publik;

b. mendorong partisipasi masyarakat dalam proses pengambilan kebijakan publik;

c. meningkatkan peran aktif masyarakat dalam pengambilan kebijakan publik dan pengelolaan Badan Publik yang baik;

d. mewujudkan penyelenggaraan negara yang baik, yaitu yang transparan, efektif dan efisien, akuntabel serta dapat dipertanggungjawabkan;

e. mengetahui alasan kebijakan publik yang mempengaruhi hajat hidup orang banyak;

f. mengembangkan ilmu pengetahuan dan mencerdaskan kehidupan bangsa; dan/atau

g. meningkatkan pengelolaan dan pelayanan informasi di lingkungan Badan Publik untuk menghasilkan layanan informasi yang berkualitas.

\section{SISI TEORI TRANSPARANSI}

Teori keagenan (Agency Theory) diyakini sebagai asal usul pentingnya transparansi keuangan. Teori keagenanan yang dikenal dalam lingkup manajemen perusahaan menjelaskan adanya hubungan antara agen (manajer atau pengelola perusahaan) dengan prinsipal (pemilik modal, pemilik saham).

Dalam hubungan keaganen ini, agen yang diberi tugas mengelola sumber daya perusahaan - termasuk keuangan - sangat mungkin mengambil keputusan yang menguntungkan diri sendiri, dan mengabaikan kepentingan pemilik (prinsipal). Hal itu dapat terjadi dalam hubungan keagenan karena agen menguasai banyak informasi terkait sumber daya, program dan aktivitas operasi perusahaan. Di sisi lain prinsipal yang diasumsikan jauh dari kegiatan operasional organisasi, tidak terlibat dalam manajemen, dan sangat minim informasi. Dalam kondisi ini muncul masalah asimetri informasi - kondisi dimana agen memiliki banyak informasi dan dapat mengambil keputusan yang 
menguntungkan dirinya sendiri, sedang prinsipal yang kekurangan informasi sangat mungkin dirugikan dengan keputusan agen. Untuk itu mereka harus membuat laporan (menyampaikan informasi) kepada pemilik.

Informasi yang disampaikan oleh agen kepada prinsipal harus diuji (diverifikasi) kebenarannya. Informasi yang terkait dengan keuangan dalam konsep akuntansi dikerjakan oleh pemeriksa ekternal.

Proses lahirnya kebutuhan transparansi informasi dalam teori keagenan digambarkan dalam Gambar 1.

\section{Gambar 1}

Transparansi Informasi Dalam Teori Keagenan

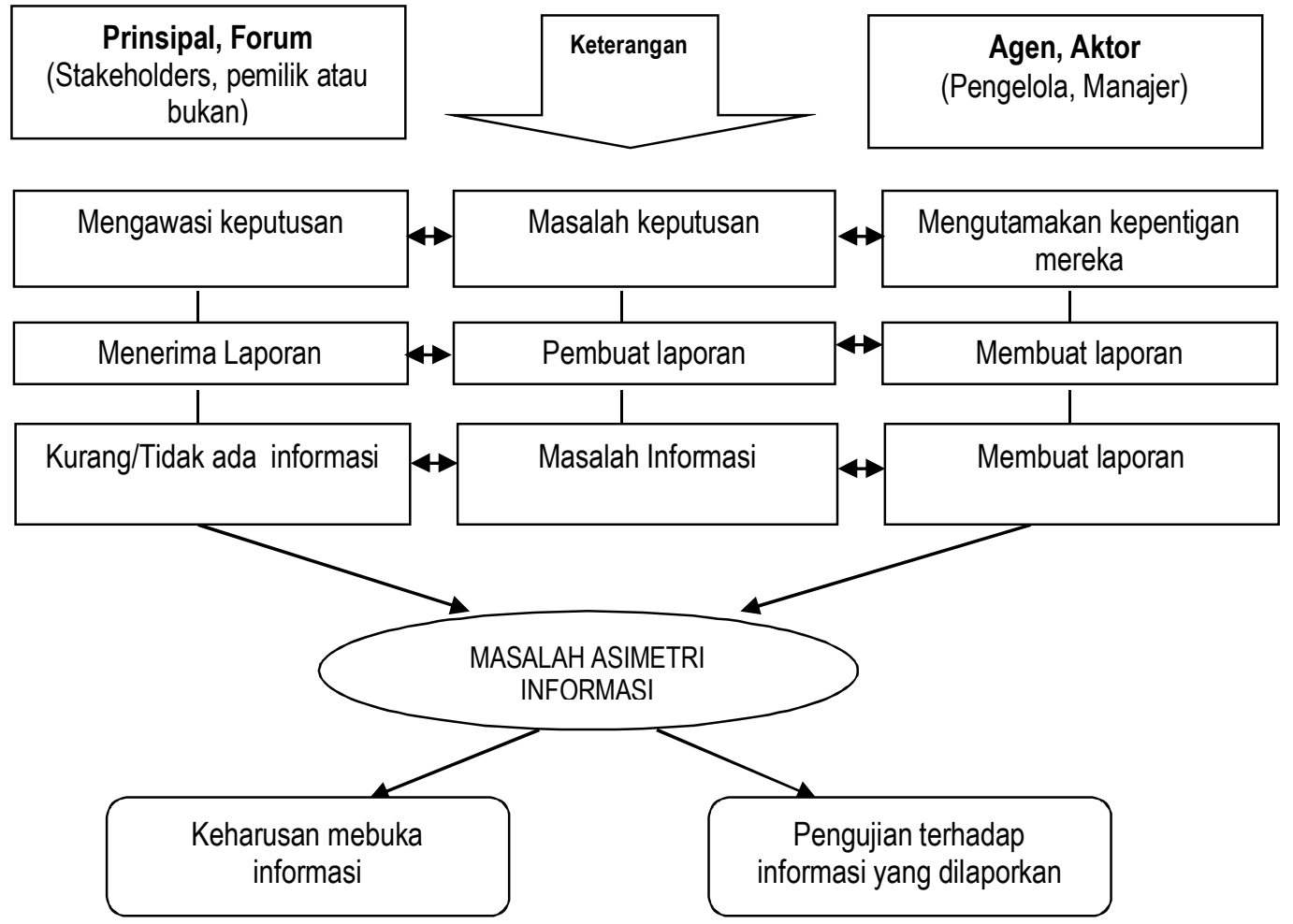

Pengertian transparasi juga dikenal dalam administrasi pemerintahan. Krina (2003:14) menjelaskan transparansi sebagai prinsip yang menjamin akses atau kebebasan bagi setiap orang untuk 
memperoleh informasi tentang penyelenggaraan pemerintahan, yakni informasi tentang kebijakan, proses pembuatan dan pelaksanaanya, serta hasil-hasil yang dicapai. Menurut Mardiasmo (2009 : 18) yang mengutip pendapat UNDP menyatakan bahwa transparasi dibangun atas dasar kebebasan memperoleh informasi. Informasi yang berkaitan dengan kepentingan publik secara langsung dapat diperoleh mereka yang membutuhkan. Transparasi dapat diketahui banyak pihak mengenai pengelolaan keuangan daerah dengan kata lain segala tindakan dan kebijakan harus selalu dilaksanakan secara terbuka dan diketahui oleh umum.

Sejumlah temuan penelitian di berbagai Negara menjelaskan bahwa pemerintah di negara demokrasi telah menyadari bahwa terciptanya keterbukaan (transparency) informasi bagi publik berdampak positif bagi kehidupan sosial, politik, ekonomi, dan hukum. Transparansi akses informasi menjadi salah satu hal penting dalam pengawasan terhadap kebijakan dan program pemerintah.

Dalam konsep administrasi publik disebutkan bahwa hak atas informasi meliputi Mardiasmo (2009):

1. Hak publik untuk memantau atau mengamati perilaku pejabat publik dalam menjalankan fungsi publiknya (right to observe);

2. Hak publik untuk mengakses informasi (public access to information);

3. Hak publik untuk berpatisipasi dalam proses pembentukan kebijakan (right to participate);

4. Kebebasan berekspresi yg salah satunya diwujudkan kebebasan pers (free \& responsible pers);

5. Hak publik untuk mengajukan keberatan apabila hak di atas diabaikan (right to appeal) baik melalui administrasi maupun adjudikasi (mengunakan sarana pengadilan semu, arbitrasi maupun pengadilan). 


\section{REGULASI TRANSPARANSI KEUANGAN}

Pada bagian ini dijelaskan regulasi transparansi keuangan dalam 3 tahapan siklus keuangan yaitu: tahapan penganggaran, tahapan pelaksanaan, dan tahapan pelaporan.

\section{(1) Transparansi Tahap Penganggaran}

Ketentuan yang mengharuskan transparansi dalam tahapan penganggaran (penyusunan APBD) diatur dalam Pasal 103 Permendagri 13 tahun 2006 tentang Petunjuk Pelaksanaan Pengelolaan Keuangan Daerah. Dalam pasal tersebut disebutkan bahwa;

a. Rancangan peraturan daerah tentang APBD yang telah disusun oleh PPKD disampaikan kepada kepala daerah;

b. Rancangan peraturan daerah tentang APBD sebagaimana dimaksud pada ayat (1) sebelum disampaikan kepada DPRD disosialisasikan kepada masyarakat;

c. Sosialisasi rancangan peraturan daerah tentang APBD sebagaimana dimaksud pada ayat (2) bersifat memberikan informasi mengenai hak dan kewajiban pemerintah daerah serta masyarakat dalam pelaksanaan APBD tahun anggaran yang direncanakan;

d. Penyebarluasan rancangan peraturan daerah tentang APBD dilaksanakan oleh sekretaris daerah selaku koordinator pengelolaan keuangan daerah.

Selain itu, transparansi dalam tahap penganggaran diatur dalam PP 56/2005 tentang Sistem Informasi Keuangan Daerah (SIKD). Dalam aturan ini diatur bahwa pemerintah daerah menyelenggarakan SIKD di daerah masing-masing dengan menyampaikan informasi keuangan kepada masyarakat. Pasal 11 dan 12 menyebutkan ketentuan tersebut:

Pasal 11

Pemerintah Daerah menyelenggarakan SIKD di daerahnya masingmasing.

Pasal 12

Penyelenggaraan SIKD sebagaimana dimaksud dalam Pasal 11 mempunyai tujuan: 
a. membantu Kepala Daerah dalam menyusun anggaran daerah dan laporan pengelolaan keuangan daerah;

b. membantu Kepala Daerah dalam merumuskan kebijakan keuangan daerah;

c. membantu Kepala Daerah dan instansi terkait lainnya dalam melakukan evaluasi kinerja keuangan daerah;

d. membantu menyediakan kebutuhan statistik keuangan daerah;

e. menyajikan Informasi Keuangan Daerah secara terbuka kepada masyarakat; dan

f. mendukung penyediaan Informasi Keuangan Daerah yang dibutuhkan dalam SIKD secara nasional.

\section{(2) Transparansi Tahap Pelaksanaan}

Pengaturan transparansi dalam tahap pelaksanaan anggaran dapat ditemukan dalam Permendagri 13 tahun 2006, khususnya pada pasal yang mengatur Pengendalian Internal

a. Dalam rangka meningkatkan kinerja transparansi dan akuntabilitas pengelolaan keuangan daerah, kepala daerah mengatur dan menyelenggarakan sistem pengendalian intern di lingkungan pemerintahan daerah yang dipimpinnya.

b. Pengendalian intern sebagaimana dimaksud pada ayat (1) merupakan proses yang dirancang untuk memberikan keyakinan yang memadai mengenai pencapaian tujuan pemerintah daerah yang tercermin dari keandalan laporan keuangan, efisiensi dan efektivitas pelaksanaan program dan kegiatan serta dipatuhinya peraturan perundang-undangan.

c. Pengendalian intern sebagaimana dimaksud pada ayat (2) sekurang-kurangnya memenuhi kriteria sebagai berikut:

(1) terciptanya lingkungan pengendalian yang sehat,

(2) terselenggaranya penilaian risiko,

(3) terselenggaranya aktivitas pengendalian,

(4) terselenggaranya sistem informasi dan komunikasi, dan

(5) terselenggaranya kegiatan pemantauan pengendalian.

Penyelenggaraan pengendalian intern sebagaimana dimaksud pada ayat (1) berpedoman pada ketentuan peraturan perundangundangan.

Selain itu, transpransi tahap pelaksanaan diatur dalam pengadaan barang/jasa (Peraturan Presiden Nomor 54/tahun 2010). Dalam regulasi ini Pemerintah mengharuskan keterbukaan informasi dalam pengadaan barang secara elektronik. Pasal 106 dan 107 yang berbunyi: 
Pasal 106:

(1) Pengadaan Barang/Jasa Pemerintah dapat dilakukan secara elektronik.

(2) Pengadaan Barang/Jasa secara elektronik dilakukan dengan cara e-tendering atau e-purchasing.

Pasal 107:

Pengadaan Barang/Jasa Pemerintah secara elektronik bertujuan untuk:

(1) meningkatkan transparansi dan akuntabilitas;

(2) meningkatkan akses pasar dan persaingan usaha yang sehat;

(3) memperbaiki tingkat efisiensi proses Pengadaan;

(4) mendukung proses monitoring dan audit; dan

(5) memenuhi kebutuhan akses informasi yang real time.

\section{(3) Transparansi Tahap Pelaporan dan Pemeriksaan}

Regulasi yang mengharuskan transparansi diatur dalam (1) PP 24/2005 dan PP 71/ 2010, (2) UU 15/2004, dan (3) PP 3/2007. Dalam PP 24/2005 dan PP 71/ 2010 yang mengatur Kerangka Konseptual Standar Akuntansi Pemerintahan (SAP) disebutkan kelompok utama pengguna laporan keuangan pemerintah: (1) masyarakat, (2) para wakil rakyat, lembaga pengawas, dan lembaga pemeriksa; (3) pihak yang memberi atau berperan dalam proses donasi, investasi, dan (4) pinjaman; dan pemerintah. Sebagai pengguna informasi, warga masyarakat pertamatama berhak atas laporan keuangan yang disusun pemerintah daerah. Warga masyarakat sebagai pengguna informasi keuangan harus mendapatkan laporan keuangan sesuai ketentuan di atas.

Dalam Pasal 19 UU 15/2004 tentang Pemeriksaan Pengelolaan Dan Tanggung Jawab Keuangan Negara diatur bahwa Laporan Hasil Pemeriksaan (LHP) yang telah disampaikan kepada lembaga perwakilan, dinyatakan terbuka untuk umum. Laporan hasil pemeriksaan ini tidak termasuk laporan yang memuat rahasia negara yang diatur dalam peraturan perundang-undangan. Ketentuan ini menjelaskan bahwa 
masyarakat berhak memperoleh informasi dari hasil pemeriksaan BPK (Pasal

Regulasi lain yang mengatur transparansi dapat ditemukan dalam PP 3/2007 tentang Laporan Penyelenggaraan Pemerintahan Daerah Kepada Pemerintah, Laporan Keterangan Pertanggungjawaban Kepala Daerah Kepada Dewan Perwakilan Rakyat Daerah, Dan Informasi Laporan Penyelenggaraan Pemerintahan Daerah Kepada Masyarakat ILPPD).

Pasal 27 PP 3/2007 ini mengatur sebagai berikut:

(1) Kepala daerah wajib memberikan informasi LPPD kepada masyarakat melalui media cetak dan/atau media elektronik.

(2) Informasi LPPD kepada masyarakat disampaikan bersamaan dengan penyampaian LPPD kepada Pemerintah.

(3) Muatan informasi LPPD merupakan ringkasan LPPD.

(4) Masyarakat dapat memberikan tanggapan atas informasi LPPD sebagai bahan masukan perbaikan penyelenggaraan pemerintahan.

(5) Tata cara penyampaian informasi dan tanggapan atau saran dari masyarakat atas LPPD sebagaimana dimaksud pada ayat (1) diatur lebih lanjut dengan Peraturan Menteri.

\section{FAKTOR YANG MENDESAK TRANSPARANSI KEUANGAN}

Desakan transparansi keuangan dalam satu dekade terakhir makin menguat karena beberapa faktor. Faktor pertama ialah tuntutan publik untuk peningkatan efisiensi dan efektifitas belanja publik. Publik semakin sadar bahwa kebijakan yang dijalankan pemerintah termasuk kebijakan belanja harus mendapat pengawasan ketat, karena hanya dengan pengawasan yang baik pemerintah semakin berhati-hati dalam merencanakan dan melaksanakan belanja. Pengawasan masyarakat terhadap kebijakan publik ini hanya dimungkinkan bila tercipta transparansi keuangan daerah.

Faktor kedua, bahwa warga semakin sadar untuk berperan dalam mengawasi dan mendorong pemberantasan korupsi. Berbagai regulasi telah memberi peluang kepada warga ikut menyuarakan pemberantasan 
korupsi. Dampak korupsi telah dipahami banyak warga, dan jumlah ini terus bertambah karena berbagai penyiaran dan kampanye melawan korupsi selama ini. Informasi yang transparan tentang keuangan akan membantu publik mengawasi prilaku korupsi.

Faktor ketiga, transparansi keuangan juga semakin dimungkinkan oleh kemajuan teknologi informasi. Penyajian informasi kepada publik banyak dipermasalahkan karena tingginya biaya untuk memproduksi informasi. Dengan perkembangan teknologi terutama teknologi informasi - seperti internet - maka permasalahan tingginya biaya informasi ini sudah dapat diatasi. Warga juga dapat memperoleh biaya informasi yang murah dengan mengakses informasi dengan menggunakan perangkat warnet dan modem yang makin banyak tersedia di perkotaan.

Faktor keempat ialah ditetapkannya perundangan tentang keterbukaan informasi publik - KIP (UU 14/2008). Lahirnya undangundang tentang KIP semakin memperjelas kebijakan Negara untuk melaksanakan transparansi informasi. KIP ini secara meluas telah disebarkan ke warga masyarakat, dan mereka terus menanti wujud dan janji pemerintah ini.

Faktor kelima ialah kebebasan menyatakan pendapat. Dalam alam demokrasi sekarang ini kebebasan menyatakan pendapat semakin disadari oleh banyak orang. Pernyataan pendapat ini diwujudkan dalam bentuk tulisan atau lisan yang menuntut hak-hak publik, termasuk hak memperoleh informasi. Dengan semakin luasnya kebebasan menyatakan pendapat, maka diperkirakan warga yang sadar dan menuntut hak memperoleh informasi akan semakin meningkat di masa yang akan datang.

\section{DESAKAN TRANSPARANSI DI PAPUA}

Transparansi keuangan di Provinsi Papua banyak mendapat perhatian media dan pengamat kebijakan publik. Hal ini dimungkinkan karena empat kondisi: 
Kondisi pertama yaitu terbukanya temuan hasil pemeriksaan BPK untuk diakses warga. Transparansi hasil pemeriksaan BPK yang mengungkapkan berbagai jenis temuan BPK seperti kerugian daerah, dan belanja yang tidak dipertanggung-jawabkan, memungkinkan warga menggunakan informasi untuk pengawasan dan mendesak perbaikan dalam akuntabilitas keuangan.

Kondisi kedua, yaitu kurangnya konsistensi dalam pemberian sanksi terhadap pejabat yang telah dinyatakan bersalah. Wujud transparansi yang dituntut warga ialah siapa pun yang telah dinyatakan bersalah harus dikenai hukuman dan sanksi. Dalam pengamatan warga, masih banyak kejadian dan peristiwa penyalahgunaan keuangan yang dibawa ke meja hijau, namun sanksi yang dijatuhkan seringkali tidak transparan. Karena kondisi ini maka kepercayaan warga terhadap pemerintah dan penegak hukum makin menurun.

Kondisi ketiga, yaitu wacana dan perselisihan elit Papua di media massa. Sudah merupakan informasi umum bahwa media cetak di Papua memuat perselisihan dan saling tuding penyalahgunaan dana antara elit Papua, seperti dalam masalah deposito uang Rp. 1,8 trilyun oleh Pemda Provinsi Papua. Saling tidak percaya antar elit Papua juga terjadi antar pejabat Provinsi dan Kabupaten/Kota, seperti dalam kasus pembagian antar dana infrastruktur Pemda Provinsi dan Kabupaten yang menyebabkan beberapa bupati pegunungan keluar dari pertemuan (rapat kerja) tahun 2008.

Kondisi keempat ialah kemiskinan yang dinilai belum tersentuh secara berarti sementara dana Otsus segera berakhir. Banyak warga tidak percaya bahwa uang Otsus dikelola secara baik, karena secara nyata warga melihat kemiskinan yang belum disentuh oleh pemerintah daerah. 


\section{TRANSPARANSI KEUANGAN MENURUT PEMDA}

Pemerintah daerah di Papua menerjemahkan transparansi dalam beberapa bentuk. Dalam beberapa diskusi dan pernyataan pejabat daerah menyatakan bahwa mereka sudah akuntabel dan transparan. Dalam pemahaman sejumlah pejabat daerah transparansi diartikan sebagai salah satu dan atau kombinasi kejadian berikut:

(1) Pengelolaan keuangan sudah sesuai peraturan. Regulasi yang sering disebut adalah Permendagri 13/2006.

(2) Keuangan daerah sudah diperiksa BPK, KPK, dan Inspektorat.

(3) Kami ini dibantu oleh tenaga akuntan professional seperti BPKP, UGM dll

(4) Dana Otsus sudah dialokasikan ke kab/kota (60\%)

(5) Dana RESPEK dialokasikan ke kampung lewat Bank Papua

(6) Sudah ada bantuan kepada lembaga keagamaan

(7) Uang Otsus terlambat dicairkan

(8) Uang Otsus terlambat dipertanggungjawabkan kabupaten/kota

(9) Penyebutan sumber dana kegiatan

\section{CUKUPKAH TRANSPARANSI KEUANGAN DI PAPUA?}

Dengan menggunakan beberapa regulasi yang mengatur transparansi keuangan, seperti dikemukakan di muka, dapat dinilai bahwa Pemda Provinsi Papua, dan Pemerintah Kabupaten dan Kota belum sepenuhnya transparan dalam pengelolaan keuangan daerah.

Beberapa fakta kewajiban transparansi informasi yang tidak disediakan Pemda di Papau antara lain:

(1) Sosialisasi RAPBD sebelum pembahasan di DPRD belum dilaksanakan seperti yang diharuskan oleh Permendagri 13 tahun 2006;

(2) Pemda belum menyelenggarakan Sistem Informasi Keuangan Daerah (SIKD) sesuai ketentuan PP 56 tahun 2005; 
(3) Pemda belum menyediakan ILPPD sesuai ketentuan PP 3 tahun 2007.

(4) LHP BPK belum bisa diakses masyarakat sesuai UU 15 tahun 2005.

(5) Perdasus Pengelolaan Dana Otsus tidak diselesaikan, sesuai kehendak UU 21 tahun 2001

\section{RESISTANSI TERHADAP TRANSPARANSI}

Perlawanan terhadap transparansi (resistensi) dapat muncul karena beberapa alasan.

(1) Ketakutan akan dampak tranparansi informasi.

(2) Pertimbangan bahwa warga tidak membutuhkan informasi keuangan,

(3) Pertimbangan bahwa warga tidak memiliki pengetahuan untuk memahami informasi keuangan,

(4) Transparansi dapat mengecilkan kuasa dan peran yang telah dimiliki elit dan pengambil kebijakan publik.

\section{DAMPAK LACK OF TRANSPARENCY}

Kalau transparansi informasi keuangan terus dihambat; ada beberapa konsekwensi negatif yang hadir dalam pemerintahan dan pembangunan di Papua:

(1) Masalah korupsi semakin sulit diatasi. Korupsi sebagai musuh bersama sangat sulit dilawan bila warga tidak diberi kesempatan untuk mengawasi, dan pengawasan warga hanya efektif bila transparansi keuangan dimungkinkan.

(2) Warga tidak optimal berperan aktif dalam pembangunan. Transparansi memungkinkan warga masyarakat memahami kebijakan dan pembangunan yang direncanakan pemerintah daerah. Dengan memahami kebijakan dan rencana, warga masyarakat akan ikut secara suka rela dan optimal dalam menunjang pembangunan. 
(3) Masalah pelayanan publik tidak akan optimal. Pelayanan publik, seperti dalam bidang kesehatan dan pendidikan dapat didorong melalui transparansi pengelolaan keuangan. Transparansi yang dilakukan melalui pemberian informasi kepada pasien dapat menurunkan pungutan liar yang menghambat keluarga miskin memperoleh layanan kesehatan di rumah sakit dan puskesmas.

(4) Papua sulit keluar dari kemiskinan. Program dan kegiatan pemberantasan kemiskinan banyak menyalurkan bantuan kepada kelompok keluarga dan warga miskin; namun banyak orang meyakini bahwa sejumlah bantuan itu tidak sampai pada target dan sasarannya. Hanya dengan menciptakan transparansi informasi keuangan kepada warga, peluang memotong hak-hak warga miskin dapat diperkecil.

(5) Kepercayaan publik kepada pemda, dewan dan elit Papua lainnya sulit ditingkatkan. Banyak penelitian lapangan menjelaskan bahwa transparansi berpengaruh positif terhadap kepercayaaan; artinya kepercayaan warga masyarakat terhadap pemerintah semakin meningkat sejalan dengan membaiknya transparansi keuangan.

(6) Optimalisasi pembangunan di era Otsus kurang optimal; sehingga suara kegagalan akan terus kita dengar. Banyak tuntutan di Papua agar dana Otsus dikelola secara akuntabel dan transparan. Tuntutan transparansi belum diwujudkan Pemerintah Daerah sampai saat ini. Beberapa contoh adalah ketidak patuhan pemerintah daerah terhadap regulasi transparansi sebagaimana pada Bagian $\mathrm{C}$ di muka.

\section{KESIMPULAN DAN SARAN}

\section{Kesimpulan}

Beberapa kesimpulan yang dapat disampaikan pada bagian akhir ini antara lain: 
a. Transparansi keuangan merupakan proses penyampaian informasi keuangan secara terbuka oleh pemerintah daerah kepada prinsipal (warga masyarakat);

b. Transparansi keuangan antara lain bertujuan untuk menilai kinerja keuangan pemda, meningkatkan pengawasan, dan partisipasi warga dalam pembangunan;

c. Transparansi telah diatur dalam sejumlah regulasi dan perlu mendapat diperhatikan dan dipatuhi pemerintah daerah;

d. Transparansi keuangan dan kebijakan publik perlu terus dikembangkan dan ditingkatkan untuk menjaga kepercayaan publik kepada pemerintah daerah.

\section{Saran}

Dalam meningkatkan transparansi keuangan diperlukan sejumlah kebijakan antara lain:

a. Transparansi melalui kepatuhan menjalankan regulasi, seperti sosialisasi anggaran sebelum dibahas dewan, penyelenggaraan SIKD, penyampaian ILPPD kepada masyarakat, dan aksesibilitas warga terhadap LKPD dan LHP BPK;

b. Peningkatan kapasitas dewan untuk menjalankan fungsi dan peran dewan menegakkan dan mengawasi pelaksanaan regulasi transparansi keuangan;

c. Pengambangan komunikasi efektif antara dewan-eksekutif untuk mengurangi konflik di media;

d. Peningkatan peran media melalui pengembangan kapasitas media (wartawan) dalam memahami berbagai aturan pengelolaan keuangan daerah, termasuk kepekaan mereka untuk tidak menyulut konflik di level masyarakat;

e. Peningkatan transparansi pengelolaan dana di tingkat bawah (masyarakat) melalui, antara lain: 
- Dana RESPEK di Bank Papua perlu diaudit dan diungkapkan kepada warga;

- Kampung yang sudah mencairkan dana diumumkan oleh RRI lokal atau surat kabar.

f. Kebijakan transparansi di tingkat lapangan dengan: (1) membuat papan proyek, atau deseminasi saat kegiatan dilaksanakan, (2) penyebutan dana untuk belanja barang modal yang dituliskan di bagian yang mudah dibaca oleh warga, seperti tulisan Bantuan Dana Otsus yang dituliskan disamping bus mahasiswa, dan sebagainya.

\section{DAFTAR PUSTAKA}

Bappeda Provinsi Papua. 2007. Evaluasi Pelaksanaan Lima Tahun Otonomi Khusus Papua, manuskrip. Universitas Cenderawasih, Jayapura. .2009a. Laporan Monitoring Dan Evaluasi Pelaksanaan Program PPD Respek 2007 Dan PNPM Mandiri Respek 2008 Provinsi Papua. Jayapura. .2009b. Studi Dampak RESPEK Terhadap

Kehidupan Sosial Ekonomi Masyarakat di Kampung. Jayapura.

Krina. 2003. Indikator dan Alat Ukur Prinsip Transparasi, Partisipasi dan

Akuntabilitas. Web: http://www.goodgovernance.com

Kristiansen, S., Dwiyanto, A., Pramusinto, A., and Putranto, E. A. 2008. Public Sector Reforms and Financial Transparency: Experiences from Indonesian Districts. Contemporary Southeast Asia Vol. 31, No.1, pp. 64-87.

Kementerian Dalam Negeri Republik Indonesia. 2007. Peraturan Menteri Dalam Negeri Nomor 59 Tahun 2007 tentang Perubahan atas Peraturan Menteri Dalam Negeri Nomor 13 Tahun 2006 Tentang Pedoman Pengelolaan Keuangan Daerah. Jakarta.

Kementerian Keuangan Republik Indonesia. 2002. Keputusan Menteri Keuangan Nomor Nomor 47/KMK.07/2002 Tentang Tata Cara Penyaluran Dana Otonomi Khusus Propinsi Papua. Jakarta. 
Medina, C and Rufín, R. 2015. Transparency Policy and Students' Satisfaction and Trust. Transforming Government: People, Process and Policy Vol. 9 No. 3, 2015 pp. 309-323

Pemerintah Daerah Provinsi Papua. 2004. Peraturan Daerah Provinsi Papua Nomor 2 tahun 2004 tentang Pembagian Dana Otsus Papua. Jayapura.

Pemerintah Republik Indonesia. 1999. Undang-Undang Nomor 39 tahun 1999 tentang Hak Asasi Manusia. Jakarta.

2001. Undang-Undang Nomor 21 tahun 2001 tentang Otonomi Khusus Bagi Provinsi Papua. Jakarta.

2003. Undang-Undang Nomor UndangUndang Nomor 17 tahun 2003 tentang Keuangan Negara. Jakarta.

.2004a. Undang-Undang Nomor 1 tahun 2004 tentang Perbendaharaan Negara. Jakarta.

2004b. Undang-Undang Nomor 15 tahun 2004 tentang Pengelolaan Dan Tanggung Jawab Keuangan Negara. Jakarta.

2004c. Peraturan Pemerintah Nomor 71 tahun 2010 tentang Standar Akuntansi Pemerintahan. Jakarta.

.2005a. Peraturan Pemerintah Nomor 56 tahun 2005 tentang Sistem Informasi Keuangan Daerah. Jakarta.

.2005b. Peraturan Pemerintah Nomor 58 tahun 2005 tentang Keuangan Daerah. Jakarta. 2008. Undang-Undang Nomor 14 tahun 2008 tentang Keterbukaan Informasi Publik. Jakarta.

Salle, A. 2011. Akuntabilitas Keuangan: Studi Pengelolaan Dana Otonomi Khusus Berdasarkan Undang-Undang Nomor 21 Tahun 2001 tentang Otonomi Khusus Bagi Provinsi Papua. Disertasi, FE Unibraw, Malang. 